\title{
From Court to Playhouse and Back: Middleton's Appropriation of the Masque
}

\begin{abstract}
Bringing a thorough study of court masques to bear on reoriented readings of The Revenger's Tragedy, Women Beware Women, The Changeling, and the lesser known Your Five Gallants, I show that Thomas Middleton's intimate knowledge of the Jacobean court masque enables him to exploit its conventions, iconography, and structural functions for use in the playhouse. Middleton confidently 'deconstructs' masque dramaturgy to create a masque episode which encapsulates the play's overarching theme and engineers the resolution. At the same time, by subverting the very device used to represent the court to the world, he subtly critiques king and court.
\end{abstract}

In the early seventeenth-century, James I and his Danish queen transformed mumming, or the Tudor practice of masked dancers unexpectedly appearing at a festivity, into a phenomenon known as the court masque. A newly commissioned masque became de rigueur for Twelfth Night and Shrovetide revelry at Whitehall and an indispensable part of any celebration in the court calendar. The coming of age of Prince Henry and the creation of Charles as duke of York were both celebrated with masques. The royal wedding of Princess Elizabeth saw no fewer than three masques commissioned. Masques were performed by and for royalty, but theatrical players were caught up in the spectacle because men and boys from the principal acting companies, servants of the king after his accession, performed the speaking roles and, after 1609 , the antimasque parts, both deemed inappropriate for nobles. Masques involved numerous artists from painters to choreographers, and dramatists also found themselves caught in this intersection between palace and playhouse. As Paul Yachnin writes, several began to 'market their connections with the court to their paying audiences', inserting a masque episode into the body of a play. ${ }^{1}$ The masque on stage, or play-masque — perforce a miniaturized

Caroline Baird (c.c.baird@pgr.reading.ac.uk) is a doctoral student in the department of English literature at the University of Reading. 
version — brought something the king revelled in to the playhouse for all to enjoy vicariously. Thomas Middleton's intimate knowledge of the Jacobean court masque enabled him to exploit its conventions, iconography, and structural functions in order to experiment innovatively with how masques, or masquing components, might be deployed in the playhouse. Although Middleton was not a prolific masquewright, unlike his fellow dramatist Ben Jonson, he wrote more masques into his plays than any of his contemporaries, and up to 1611 was the only dramatist to take the device outside the repertoire of the children's troupes. ${ }^{2}$ Whether an inserted masque is extensive (giving the effect of a complete masque), reduced to a repeated entry dance, or even condensed to 'something like the abstract of a masque' (Wit at Several Weapons 5.2.340-1), ${ }^{3}$ it has a dramatic function; in The Changeling the mere rehearsal of an antimasque produces the required effect. All things considered, I suggest that the music, sophistication, and symbolism of the Jacobean masque inspired Middleton rather than the humbler Elizabethan revels. A specific Stuart masque shaped by contemporary events is sometimes the template. ${ }^{4}$ He responds swiftly to innovations in the masque form itself, and I concur entirely with Gary Taylor and Andrew Sabol's analysis that 'in the remaining decade of his career, from 1614 to 1624 , Middleton increasingly transformed plays into a de-privatized, "commons" equivalent of court masques. 5 This article argues that Middleton 'deconstructs' masque dramaturgy, confidently using its components and conventions to distil a play's themes. At the same time, by subverting the very device used to represent the court to the world, he subtly satirizes king and court.

Whilst the court masque and its politics have attracted considerable attention in recent years, much less work has focussed on the play-masque. An exception is the play-masque in Middleton's Women Beware Women (1621): for this reason my own discussion of this play will be brief. Enid Welsford's authoritative study contains a chapter of the influence of the masque on drama. ${ }^{6}$ Sarah Sutherland and M.R. Golding have written on the use of the masque in revenge tragedy, and Inga-Stina Ewbank has given an overview of the different uses of masques in some plays of the era. ${ }^{7}$ Critical discussion, though, tends to focus on the masque's 'revels', the moment when the masquers 'take out' members of the audience, and the inherent potential for surprise in the revelatory unmasking. Court masques, however, even though the masquers are dumb and the text is often minimal, contain many other constituent elements, just as important as the final dancing, which 'speak' and convey meaning. ${ }^{8}$ 
Linking contextual study of masquing conventions to nuanced, reoriented readings of canonical texts, The Revenger's Tragedy, Women Beware Women, and The Changeling, as well as the lesser known Your Five Gallants, I propose to delve deeper into some of these elements to reveal particularly imaginative reworking of the masque as a cultural and literary form. These elements include the convention for masquing suits of the same livery, the role of torch-bearers, the passion for emblems, and the 'transformation' scene. I will also look at the antimasque and its later invasion by courtiers. I will show how Middleton subverts these key components in the service of satire, whilst still keeping the masque's archetypal purpose, the restoration of order. My approach will read the final moments of The Changeling as analogous to the transformation scene of a masque, adding a hitherto unrecognized significance to the play's title, change and transformation being virtually synonymous.

\section{Matching Masquing Costumes, 'Loud Music', and the Entry Dance}

In The Revenger's Tragedy (1606) arch-revenger Vindice uses masquing suits for disguise and imitation; masquing provides the play's central disguise motif. The play is set in an Italian ducal palace, yet anchoring phrases in act 1 make it clear that Middleton is writing about contemporary society and the English court. ${ }^{9}$ The masques also speak obliquely of James I's obsession with this form of revelling. In this play-masque the customary harmonious purpose of the masque is inverted, however, with the play's pervasive inversion of values signalled early on by Lussurioso's request to Hippolito to find him 'A man that were for evil only good' (1.1.80). The 'hero' has to disguise himself as a 'fine villain' (1.3.56).

As the play opens we learn that the Duchess's youngest son, Junior, has 'play'd a rape' (1.1.110) on Lord Antonio's wife and that masquing, in particular its darkness, vizards, and loud music, provided Junior with the perfect opportunity for his 'vicious minute' (1.4.39). This pre-commencement masque and the masque of 5.3 therefore 'frame' the play. Jonson and the other masquewrights devised fables, involving virtues, deities or heroic figures, around the noble masquers. Rosemond Tuve observes that 'they are not court personages acting parts in a play, but have, as themselves, been written into a dramatic piece. ${ }^{10}$ At the end, when the unmasking takes place, as Sabol explains, the understanding is that the miracles and virtues they had enacted 'were easily attainable by such eminent men as they'. ${ }^{11}$ As Antonio suggests in 
Revenger's Tragedy, however, in donning vizards some courtiers were 'Putting on better faces than their own' (1.4.29). True enough, for the masquers in this allegorical court are not the embodiments of gods, fairy kings, or virtues but the personifications of vice - Lechery (Lussurioso), Ambition (Ambitioso), Vanity (Supervacuo), and Bastardy (Spurio). The wider suggestion is, of course, that King James's courtiers regularly put on 'better faces' than their own when they too assumed masquing costumes. ${ }^{12}$

Many elements of masquing feature in the 'unsunned lodge / Wherein 'tis night at noon' (3.5.18-19), the scene of the old Duke's last 'entertainment'. Whilst not a masque as such, this entertainment is a piece of meta-court drama with vocabulary such as 'tragic business', 'show', 'property', 'part', and 'applaud' (99, 100, 101, 108) - terms that explicitly draw attention to the artifice of acting. Artifice it certainly is, as one 'performer' is Gloriana's skull, 'dressed up in tires' (43), on which Vindice has placed a modesty mask. ${ }^{13}$ With this 'bony lady' (121) Vindice, as Piato, tricks the lusty Duke into receiving the kiss of death. He has applied poison to the mask or skull so that, as the 'puppeteer', he can ensure that it will 'kiss his lips to death. / As much as the dumb thing can' (105-6). Music and dancing were strong features throughout masques, not just in the final revels, and presumably music was played in this scene - the word 'music' occurs six times in 3.5, acting as a crescendo to the moment of revenge, to this danse des morts. The skull, the very 'mort' the Duke had poisoned, dances the poisoned Duke to his grave. Lydgate's painting of the 'Dance of Death' in St Paul's was destroyed in 1549, but his translation of the French Middleton perhaps knew. It states that its purpose was 'As in a myrrowre / to-forn yn her reasoun / Her owgly fyne / may clierli ther beh-holde.' ${ }^{14}$ We can only see ourselves with a mirror, and the Duke is forced to see his ugly sin in the mirror Vindice holds up before him, the dead Gloriana. A decadent banquet always closed a masque and, in a ghoulish finale, the dying Duke is forced to watch speechless as his Duchess and his bastard arrive at the lodge for their banquet and the satisfaction of their sexual appetites, the Duchess oozing lust in her line, 'Pleasure is Banquet's guest' (218).

'Loud music' was a specific feature in court masques at two key points: the king's entry before the commencement and the 'transformation scene', the moment of metamorphosis when the masquers arrive. Hippolito's 'Thanks to loud music' (218) is heavily ironic here, used not at a regal entrance but at the Duke's departure from life having been cuckolded, humiliated, poisoned, and stabbed. The repetition of 'torch', 'night', 'noon', 'loud music', 
'minute', 'vizard', and 'poison', from Antonio's report in 1.4 of the earlier masque alongside the symbolic feasting, shows Middleton's skilful evocation of the first masque.

Lussurioso is quick to welcome the 'sweet titles' (5.1.136) he has inherited on his father's death and his nobles, sycophantic 'flesh flies' (13), are quick to propose 'revels' (165) to honour him, i.e. a masque with accompanying dancing and banqueting. Masques were tools of compliment, therefore commissioning revels might be the nobles' stake in their future at court. ${ }^{15}$ Lussurioso's most successful flatterer is told, 'Thou shalt sit next me' (5.3.37). Seats nearest to the king in the masquing room at Whitehall were sought and fought after and were a measure of worth; foreign ambassadors could be flattered or insulted by their seating allocation. ${ }^{16}$ These nobles, however, will come to regret their places of honour.

In the last seventeen lines of 5.1 we learn that Vindice and each of Lussurioso's brothers all see different opportunities presented by the masque. Supervacuo, his sights on the dukedom, announces to Ambitioso that 'A masque is treason's licence - that build upon / 'Tis murder's best face when a vizard's on' (5.2.183-4), clearly establishing that the scheming duo are going to make a further attempt on their brother's life, concealing their deed in honourable entertainment. Again the details of masques that Middleton exploits are overshadowed by the internecine bloodbath that soon follows. We learn that the Duke's brothers are 'busied to the furnishing of a masque / And do affect to make a pleasant tale on't' (5.2.12-13). This emphasis on artifice mocks the fanciful allegorical fables of court masques and their self-mythologizing and is heavily ironic since a pleasant tale it clearly is not going to be. Vindice, the consummate master of disguise, plans to assume the same masquing disguise as the brothers to fool Lussurioso. To this end he arranges 'to take pattern / Of all those suits, the colour, trimming, fashion, / E'en to an undistinguish'd hair almost' (15-17). These lines mock the work and expense involved in the design and creation of masquing costumes. Further, masquers usually wore 'en suite' or identical costumes - indeed it was the preferred form because uniformity and an orderly stage represented a peaceful, ordered kingdom. ${ }^{17}$ The sinister employment of uniformity in Revenger's Tragedy is another example of Middleton's express subversion of the harmonious aim of the court masque.

The seated Lussurioso is expecting to be honoured and entertained but, stealing a march on the 'Brothers and Bastard' (5.3.41), Vindice, Hippolito, and the two other lords who are needed to match the costumed quartet of 
brothers enter and dance. Notably, this moment is not, as is often assumed in discussions of this scene, the moment of 'revels', the 'taking out' at the end of the masque, but the beginning, perhaps the traditional short entry dance as the masque's scene is 'discovered'. Contemporary accounts of masquing at Whitehall, such as those of Sir Dudley Carleton and Sir John Harington, 'show that at least some courtly masquing occasions were nothing less than chaotic'; this is how Vindice and Hippolito can pre-empt Ambitioso's quartet. ${ }^{18}$ This court is large - Hippolito states 'There are five hundred gentlemen in the action / That will apply themselves and not stand idle' (5.2.289) - so it is easy for Vindice's masquers in identical apparel to gain access and, 'observing the true form' (5.2.18), perform their entry dance. They then unsheathe their swords and murder Lussurioso and the three favourites seated next to him and leave. Unaware of their imitators, the masked brothers (and a fourth lord) enter to 'discover' an unexpected masque scene, a quartet of murders. Masques, like state processions, aimed to ensure that 'the king's body was publicly visible at set times and was always approached with reverence.' ${ }^{19}$ The symmetry of the one-a-piece murders matches the synchronism inherent in court masque dances but 'observing the true form' of the court masque was not propping up the dead body of a murdered duke in a 'greasy doublet' (5.1.72) or murdering his heir at his installation banquet. The dance occurs before the sudden moment of miraculous transformation and metamorphosis, which is signalled by the thunder as the murders take place. Vindice notes the theatricality of thunder, 'Mark, thunder! / Dost know thy cue' (5.3.42-3), and it is interesting to compare this phrasing with Jonson's lines at the moment Truth descends in the Barriers at a Marriage, also 1606:

Princes, attend a tale of height and wonder.

Truth is descended in a second thunder,

And now will greet you with judicial state,

To grace the nuptial part in this debate,

And end with reconcilèd hands these wars. (Barriers, 224-8) ${ }^{20}$

The thunder in Revenger is of course morally ambiguous. Vindice's downfall comes when he cannot stop himself boasting to Antonio, who immediately orders his execution. Antonio's appearances frame the play; he symbolizes the judicial, vice-free ruler. The return to order was the end of all court masques and although Vindice has purged a dukedom 'vex'd with sin' (5.2.6), triggering the ambitious brothers to kill each other, he has killed two dukes; he is a murderer. He finally realizes that 'Tis time to die when we are ourselves 
our foes' (5.3.109). I am suggesting that there is a masque-like ending, except that, following the play's inversion of values, order is achieved through murder rather than divine miracle.

Middleton was not the first to use the masque for mayhem and murder. ${ }^{21}$ Of the many revenge plays in the years between Kyd's Spanish Tragedy (ca 1587) and Middleton's Women Beware Women (1621) that feature a masque episode, however, only four employ the masque itself as, to use Golding's term, a 'revenge murder machine': Marston's Antonio's Revenge (1600) and The Malcontent (1603-4) and Middleton's pair, Revenger's Tragedy and Women Beware Women. ${ }^{22}$ Marston's template is doubtless a strong influence, but Middleton builds on the violent yoking of ceremony and anarchy and makes the masque not only emblematic of the play's themes of disguise, vanity, and ambition but also a hieroglyph of the court. The many disguises, and in particular the matching of one masked quartet with another identically costumed and vizarded foursome, mirror the duplicity, doubleness, and 'smooth-brow'd treachery' 23 that courtiership required, frequently alluded to in play-texts of the era. 'Courtiers have feet o'th nines and tongues o'th' twelves. / They flatter dukes and dukes flatter themselves' (5.1.149-50), Vindice declares.

Stephen Orgel describes the masque as 'Platonic and Machiavellian; Platonic because it presents images of the good to which the participants aspire and may ascend; Machiavellian because its idealizations are designed to justify the power they celebrate'. ${ }^{24}$ In Revenger's Tragedy Supervacuo and Ambitioso plan to assassinate Lussurioso in the course of a 'pleasant tale', and Lussurioso is happy to accept the honour for the time being, but he has plans to wield his power and see his brothers 'dance next in hell' (5.3.41). The gulf between the intent of both parties and the ideal is vast. Middleton uses many elements of masquing such as its final banquet, the loud entry music, the transformation, and above all matching costumes, but all have been subverted. Nevertheless, this murderous masque does restore order and epitomizes the play's central themes of disguise and vanity.

\section{Torch-Bearers, Emblems, and Masque Songs}

In the city comedy Your Five Gallants (1607), Middleton unhinges the masque from its courtly setting and focuses on two different components, emblems and torch-bearers — both familiar parts of masque iconography. Although the masque was a court entertainment, one has only to consider 
the numerous craftsmen involved in its production, the number of servants and extended family exposed to the genre when the monarch and consort visited homes in the city and country, and the reports of the many spectators, to appreciate how it entered contemporary discourse. But if the masque was popular, the passion for emblems and imprese was even more widespread. ${ }^{25}$ As Rosemary Freeman states, the emblem became part of the language of the age, used by preachers, teachers, and poets. ${ }^{26}$ Designs found their way from emblem books to homes - on embroidered clothing, tapestries, carpets, wall panels, and ceilings; on book covers and portraits. ${ }^{27}$ It was, however, in the masque, as Allarydce Nicoll states, that 'the fashion for the courtly impresa and for the emblem-book reached its completest expression'. ${ }^{28}$ The masquers were 'living pictures' plucked from emblem books. ${ }^{29}$ Samuel Daniel refers to the twelve goddesses of his 1604 masque as 'the hieroglyphic of empire and dominion'. ${ }^{30}$ In Five Gallants Middleton burlesques the pretentious passion for emblems and the self-mythologizing entailed in both the impresa and the court masque. ${ }^{31}$

Denizens of Jacobean London, the eponymous five gallants are genial rogues - a cheater, a lecher, a broker, a thief, and a bawd — representative of common vices. They compete, with the virtuous Fitzgrave, as suitors to a wealthy heiress, Katherine. The play has little by way of a conventional plot. Rather, in a series of vignettes, it dramatizes social interaction and mischief, catering to the vogue for cony-catching roguery. Metatheatricality allied to contemporary haunts, including the gaming room at the fashionable Mitre tavern and the middle aisle of Paul's, would have clearly connected the fictive and real for a contemporary audience - Ralph Alan Cohen describes the play as a 'gallery of mirror images' for spectators. ${ }^{32}$ Fitzgrave disguises himself, very much like Vindice, as a malcontent, a 'credulous scholar, easily infected / With fashion, time, and humour' (1.2.92-3). He winds himself into his rivals' trust to witness their various rogueries.

At the end of the month's respite that Katherine has requested from her suitors, Goldstone suggests: 'What if we five presented our full shapes / In a strange, gallant, and conceited masque?' (4.7.222-3). They unwittingly commission their rival, Fitzgrave, in his disguise as the scholar Bowser, to be the masque's 'Poet' (226), requiring of him 'a little of thy brain for a device to present us firm, which we shall never be able to do ourselves ... and with a kind of speech wherein thou mayst express what gallants are bravely' (2547). Bowser employs a painter to emblazon shields with designs and imprese that succinctly emblematize the untrustworthiness of each gallant. He gives 
his co-conspirator gentlemen-gallants (and the audience) a preview. Goldstone's device is three silver dice, an appropriate symbol for the 'cheating-gallant'. The emblem of the bawd gallant, Primero, is a pearl hidden in a cave, with the motto 'occultos vendit honores' (5.1.101), 'he sells hidden honours'. Frip, who as the broker-gallant dresses in pawned clothes, is represented by a cuckoo. Tailby, the whore-gallant, misinterprets his emblem of a candle in a corner to mean 'my light is yet in darkness till I enjoy her' (160) and, like his companions, he does not understand his Latin motto 'consumptio victus' (158), 'a consumption of sustenance', nor his later introduction by Bowser, anglicized for the playhouse audience: 'a notorious lecher maintained by harlots' (210-11). The emblem of 'the pocket-gallant', Pursenet, is an empty purse, his motto 'Alienis ecce crumenis' (86-7), 'behold the purse of another'. Five Gallants is like a crossword with both cryptic and simple clues. The Latin mottoes offered the sophisticated spectators in the audience the satisfaction of being able to crack the real meanings because, as Nicoll says (albeit of the court audience), 'culture was to be displayed by quickness in appreciation of these things. ${ }^{33}$ Visual clues and Fitzgrave's preview aided those who did not understand Latin to have their own laugh at the gallants who are gulled by the false, yet plausible, translations of the Latin that Bowser gives them.

Peter Walls has shown that masque songs were designed to expose the mysteries of the masque's 'device. ${ }^{34}$ Following this masque's song, the masque is described:

Enter the masque, thus ordered: a torch-bearer, a shield-boy, then a masquer, so throughout; then the shield-boys fall at one end, the torch-bearers at the other; the masquers i'th'middle. The torch-bearers are the five gentlemen; the shield-boys the whores in boys' apparel; the masquers the five gallants. They bow to her; she rises and shows the like; they dance, but first deliver the shields up. $\quad(5.2 .18 \mathrm{sd})$

As Katherine reads out the Latin mottos, each gallant proudly bows in acknowledgement. When she seeks confirmation, 'Are you all as the speech and shields display you?', Goldstone answers: 'We shall prove so' (24-5). A dance follows until finally Frip presents Katherine with a chain of pearl. The ironic truth of the thrice-repeated line of the song, 'Anon you will be found' (18-19), is soon seen as Katherine immediately recognizes the chain of pearl Fitzgrave gave her. It was stolen by Pursenet's boy and has made its way round the group in a cycle of gifting and filching. 
In a court masque the whole invention is geared to the moment when the masquers remove their visors and become themselves. These masquers have already revealed their identities in bowing to the Latin imprese they did not understand, damned by their own 'invention' (5.1.72). Instead it is the torch-bearers (Fitzgrave, Piamont, Bungler, and two other gentlemen) who unmask. In an age of unlit streets torch-bearing was a routine service carried out by household servants or pages. ${ }^{35}$ Not only were torch-bearers a necessity simply to reach the masquing hall, ${ }^{36}$ but their costumes and vizards harmonized with those of the masquers whom they always equalled in number, a tradition established from the first Jacobean masque. ${ }^{37}$ As Anne Daye explains, they 'amplified the masquers' theme, emphasized their status', and heightened the wonder of the spectators. ${ }^{38}$ The masquers should be incarnations of the qualities they portray and unmask to reveal their glorious selves; the torch-bearers' role is a passive one. Instead, in a reversal of roles which would not have escaped the audience's notice, the gentlemen torch-bearers illuminate the situation in a very different way, so that the wonder is that of the masquers - thieves, cheats, and lechers - as the torch-bearers 'blast' 39 their marriage hopes. Fitzgrave, the true gentleman, wins Katherine's hand and matches four of the gallants with the courtesans from Primero's brothel disguised as shield-boys. Shield-boys seem to be Middleton's innovation in masquing, but a shield-bearer carried the shield of a warrior or king. ${ }^{40}$ These courtesans are not protective, subservient shield-bearers but spirited women who loathe the gallants 'worse than the foul'st disease' (5.2.66), even though they eventually agree to marriage for the protection it affords them. They ultimately use the men as shields with the result that traditional hierarchy and order is re-established through the masque, as in Revenger's Tragedy. As Beaumont and Fletcher's Strato states, wedding masques 'must commend their king, and speak in praise of the assembly, bless the bride and bridegroom in person of some god; they're tied to rules of flattery'. ${ }^{41}$ Fitzgrave, who declares at the masque's rehearsal, 'This is my crown' (5.1.122), is the metaphorical king and god in this play-masque. As Cohen says, 'the indoor sport of royalty', the masque, has been used as a mirror and parodied. ${ }^{42}$ Pursenet's assumption that Fitzgrave's poetic ranting when he realizes his pocket has been picked is 'some pageant plot or some device for the tilt-yard' (2.1.242), and his hope to meet him in 'some court-alley' (3.2.21), bring the object of the satire suggestively close to Whitehall.

Middleton has again subverted specific elements of masquing convention, the song revealing the thief, the emblems showing the gallants' vices (not 
their virtues), and the torch-bearers, who prove to be socially and morally privileged, disciplining (not enhancing) the masquers. This wooing masque has also encapsulated the drama's themes: the concern for reputation, the ubiquity of bluffing, and the constant cycle of service, reward, and gratitude that the patronage system encouraged, so clearly described in Pursenet's epiphany, when he ambushes Tailby in Coombe Park and finds the pearl chain his boy stole from Katherine:

Why this is the right sequence of the world: a lord maintains her, she maintains a knight, he maintains a whore, she maintains a captain. So, in a like manner, the pocket keeps my boy, he keeps me, I keep her, she keeps him; it runs like quicksilver from one to another'.

(3.1.135-9)

\section{Antimasques and the Transformation Scene}

Around 1608 a new element, the 'antimasque', was introduced into the masque. For the Masque of Queens (2 February 1609), Jonson writes, 'her Majesty ... has commanded me to think on some dance or show that might precede hers, and have the place of a foil or false masque. ${ }^{43}$ The previous year an 'antimasque of boys', 'most anticly attired', had represented 'the Sports, and pretty Lightnesses, that accompany Love' in Jonson's masque for Lord Haddington's marriage. ${ }^{44}$ Originally this was just an antic dance, but the idea took hold and the 'antimasque' developed. Not only did it vary the diet but it also produced, as Queen Anna requested, a contrast to enhance the effect of the masquers' entrance and emphasize the theme. In Queens, Jonson's antimasquers are eleven hags and their dame, representing 'Ignorance, Suspicion, Credulity, etc.' (15-16), who appear from 'an ugly hell' accompanied by 'a kind of hollow and infernal music' $(21,25)$ and fall into a 'magical dance, full of preposterous change and gesticulation' (318-19). The scene changes and they vanish, dispelled by twelve queens. The antithesis, 'the opposition between the ideal and its obverse, or between masque and antimasque', writes Sabol, 'is the basic frame upon which Jonson built his pieces. ${ }^{45}$

As in the playhouse, where comedic subplots were sometimes more popular than the main plot, antimasques became so popular that by 1613 it was normal to have two. James himself found antimasques highly amusing and after the second antimasque of the Masque of the Inner Temple (1613) 'It 
pleased his Majesty to call for it again at the end, as he did likewise for the first anti-masque, but one of the Statues by that time was undressed' (2468). ${ }^{46}$ Word clearly spread of the king's delight in this comedic element, and some antimasque dances from court productions were transferred almost intact into plays. ${ }^{47}$ Middleton responds to the popularity of the device but resolutely uses the spelling 'antemasque. ${ }^{48}$ Taylor conjectures that this is because his oppositions 'are not absolute antitheses but simply precursors' ${ }^{49}$ In Wit at Several Weapons Middleton and Rowley personify antemasque and masque. The Old Knight, Sir Perfidious Oldcraft, plans to marry his Niece to the wealthy, but foolish, Sir Gregory Fop in a perfidious deal whereby he pockets two-thirds of her dowry himself. He decides to trick his Niece, pretending that Fop's penniless, parasitic young companion Cunningame is the husband he intends for her, forewarning Fop:

OLD KNIGHT You shall not be seen yet: we'll stale your friend first.

If't please but him to stand for the antemasque.

SIR GREGORY Puh, he shall stand for anything: why his supper

Lies I' my breeches here; I'll make him fast else.

OLD KNIGHT Then come you forth more unexpectedly,

The masque itself, a thousand-a-year jointure:

The cloud, your friend, will be then drawn away,

And only you the beauty of the play.

He fails to see that, contrary to enhancing the superior qualities of Fop, 'the masque itself', the 'antemasque' Cunningame is much more attractive husband material. Antimasquers are meant to obstruct the courtly masquers but the masquers always defeat them, sometimes causing the chaos to vanish by their very arrival. When Masque Fop is proudly produced, however, Niece Oldcraft subjects him to continual mockery and repeated rejections until Cunningame tricks him into marrying Mirabell, the niece of the Guardianess. The eventual union of Cunningame and Niece Oldcraft is achieved during the revels or dancing in Wittipate's 'abstract of a masque' in the final act. ${ }^{50}$ This is the moment when masquers 'take out' partners from the spectators, inviting them to dance, 'raising the latter at least briefly, into the brighter and better world of the former. ${ }^{51}$ The dramatists subvert the aim of the 'taking out' and also reverse the result of the traditional antimasque/ masque conflict of the mid-reign Jonsonian masque, cleverly satirizing the court audience's delight in antimasquing. 
An 'antemasque', in its meaning of 'before', occurs in the play-masque from Women Beware Women, where it is a precursory dance that Bianca either designs or hijacks, aiming to have the censorious Cardinal, next heir to the dukedom, poisoned in a dance of cup-bearers. The stage audience has a written 'argument' (5.1.69) of the pastoral fable. When the Duke becomes confused by the opening dancers, not mentioned therein, dissembling innocence of any hand in the device, Bianca proffers: 'This is some antemasque, belike, my lord' (106). It precedes the masque, but is not an antimasque. It has the same ironic symbolism as the main masque but there is no transformation at this point. The extensive literature on this masque discusses the ironic roles of each masquer and the poetic justice meted out to all, so that the masque functions as 'a moralized metaphor', a 'revelation and a resolution. ${ }^{52}$ My interest lies in the allusion to an earlier Jonsonian masque and further Middletonian subversions. Women Beware Women is based on the story of Venetian heiress Bianca Capello, her elopement to Florence with a bank-clerk, and her seduction by the grand duke, Francesco I de Medici, as related in Malespini's Ducento novelle (1609). The sub-plot also has a literary source, but neither features a masque; this is Middleton's addition, although, as Margaret Shewring and J.R. Mulryne have shown, the weddings of Francesco (to both his first wife and Bianca) were celebrated by elaborate shows interspersed by intermedii, the manuscript descrizioni of which they consider Middleton may have consulted. ${ }^{53}$ It is more likely that the intertextual borrowings are from Jonson's Hymenaei. Mulryne points out the similarities of personnel (Juno and Hymen) and iconography (the altar, peacocks, fire). Hymenaei was written for the marriage of Frances Howard and Robert Devereux in 1606. As is well known, the marriage was a source of scandal by 1613-14 when annulment was sought, and by 1621 not only had Howard married Robert Carr, earl of Somerset, but the pair were in the Tower for murder. Hymenaei was therefore, as Shewring and Mulryne state, 'effective shorthand' for ill-conceived marriage and court scandal, drawing on 'embedded associations in the minds of the audience, including the minds of those ... who had never attended a court masque. ${ }^{54}$ John Jowett was the first to make a connection between the play's title and a ballad on the Overbury scandal, 'Mistress Turner's Farewell', which, he writes, includes the admonition 'Women by me beware. ${ }^{55}$ Combined with the deliberate alteration of the Duke's age to fifty-five, ${ }^{56}$ James's age in 1621, this detail strengthens the case for an anti-court reading. 
Dramaturgically, this play-masque is one of the closest attempts to portray a full court masque. ${ }^{57}$ It evokes typical conventions: following the antemasque there is music, then the discovery of the masque's pastoral scene, and as the nymph (Isabella) sets a censer and tapers on Juno's altar, a song or 'ditty' $(5.1 .110 \mathrm{sd})$ is sung, expounding the story. ${ }^{58}$ The two shepherds she loves (Guardiano and Hippolito) enter to add their pleas to Juno (Livia), who is 'aloft' (174). In court an upper stage for masquers was a feature of Inigo Jones's set designs. Livia's urgent demand 'let me down quickly' (168) probably alludes to Jones's elaborately engineered moving stages. ${ }^{59}$ As Barbara Ravelhofer has shown, the emphasis on 'descent' of grand masquers was pronounced. ${ }^{60}$ It was always deities or 'higher' beings that descended from mountains, the heavens or cloudscapes. ${ }^{61}$ Overcome by the poisoned fumes from Isabella's censer, Livia is forced to descend from her godly height. The gods of masques, sometimes played by Queen Anna, descended to create order. When Livia and her cupids, armed with poisoned arrows, descend, chaos ensues and all the characters (except the Cardinal) meet their ends. In recent work on gender and violence, Elizabeth Kolkovich suggests that this play shows disapproval of women's masquing at the Stuart court and its 'opportunity to sabotage masculine royal authority'. ${ }^{62}$ In the period she might have had her ears cut off, as William Prynne did in 1633 for his perceived attack on Henrietta Maria and royal theatricals. It is surely Howard, Carr and James that Middleton targets. As Laura Severt King suggests, 'the decline into chaos and brutality of a form charged with celebrating order and harmony argues that something is desperately wrong at the political center'. ${ }^{63}$ John Potter and Albert Tricomi suggest similar readings of the scene. ${ }^{64}$ The real point being made is that mythological gods, played by royal masquers, represented the absolute authority of the monarch. Juno was to decide between the suitors and resolve the predicament, creating an idyll — not kill the prospective bride and trigger annihilation. From Orgel's research we know that pastoral scenes, a commonplace, became 'an assertion of royal power', ${ }^{65}$ the king being able to tame nature. In the early Stuart masques such pastoral scenes come at the beginning and embody 'the wildness of nature' or 'untutored innocence', with the passage to 'sophistication and order ... represented by complex machines and Palladian architecture'. ${ }^{66}$ After 1616, however, the 'sequence is reversed' and pastoral settings 'appear ... at the end, and embody the ultimate ideal'. ${ }^{67}$ We cannot be sure that Middleton consciously reverses the established pattern, but the game he plays in this final 'set-match' (196) is clear: this Florentine court was never natural or 
innocent, and the innocent pawns it ensnares become 'acquainted' (2.2.439) with sin and murder. The two kisses that frame the masque, Bianca's disingenuous kiss from the Cardinal and her suicidal inhalation of the Duke's breath, contrast with the innocent kisses in scene 1 .

In 1622 Middleton collaborated, not for the first time, with William Rowley in The Changeling. ${ }^{68}$ Both dramatists were by now fluent in masquing protocol and co-authors of their own Courtly Masque: The Device called, The World Tossed at Tennis (1620). To their tragedy, they added the apparently incongruous element of an antic dance as a vital ingredient. The Changeling's source text is a fiction from the first volume (1621) of The Triumphs of Gods Revenge, written by a Calvinist merchant, John Reynolds. ${ }^{69}$ These 'histories' of brutal murders, with moralizing introductions and conclusions, were extremely popular and widely read. We know James read them, and this first volume was dedicated to Buckingham. ${ }^{70}$ Both its direct connection to the court favourite and Reynolds's own description of the castle's casemates where Alonzo is murdered as 'the Theater, whereon we shall presently see acted a mournefull and bloudy Tragedy' (T1r), must have been impossible to resist. Middleton and Rowley follow the events of the source closely, keeping key words and the precise manner of Piracquo's murder, but their poetic language, some of the most memorable of the period, transforms Reynolds's didactic prose.

The dramatists also introduce a 'foil', or what I term an 'anti-plot', analogous to the antimasque/masque bifurcation and with a similar force and relevance to the main plot. ${ }^{71}$ Like the antimasque, the anti-plot is contrasting, antic (comic, hence popular), and antique (involving ancient dances). As Sabol explains, the antimasque served as a foil 'through its emphasis on the grotesque, fantastic, or remote'. He elaborates, 'the masque ... represents the transcendent world of the macrocosm, the antimasque represents the sublunary world of men and beasts, the microcosm', frequently depicting animals and satiric in purpose. ${ }^{72}$ Moreover, although the later court masques tended to have greater numbers of masquers to antimasquers, the antithesis was more obvious with equal numbers: the evil spells of twelve witches dispelled by the arrival of twelve queens and so forth. The antimasque was an 'object on which to exercise and thus demonstrate the power of the forces of order' and the king's omnipotence. ${ }^{73}$ An 'anti-plot' of the kind I am outlining needs to do more work than a normal sub-plot, even one linked to the main storyline; it requires careful balancing — not reflecting or mirroring as Muriel Bradbrook suggests, but 'othering' with grotesques, showing what 
the masquers were not. ${ }^{74}$ In The Changeling Middleton and Rowley match the main persons of the castle plot with the other in the madhouse, as has been well documented. ${ }^{75}$ The madhouse is not in the source, although the idea may have germinated from Reynolds's Preface, which warns that it is a folly to hearken to temptation, but a misery and madnesse to follow and embrace it' (my italics). ${ }^{76}$ Further, Reynolds's Alsemero becomes jealous after marrying Beatrice-Ioana, imagining her 'unchaste with many' and 'curbes and restraines her of her liberty.' ${ }^{77}$ By devolving this element onto Alibius, a 'Mr Elsewhere', Middleton and Rowley, quite at home with the binary oppositions of court masques — witches/queens, satyrs/knights, frantics/ statues - easily create a folly/madness opposition with the 'anti-plot' set in a lunatic asylum, its inmates dressed as birds and beasts, establishing the binary opposition between perceived normality and abnormality, which is to be collapsed. Each plot presents the woman with temptation. One female character 'hearkens' to it and acts foolishly; the other 'embraces' it in a state of moral madness. In this period lunatics were considered a source of entertainment and would have been considered safely 'other'. The madness, however, turns out to be in the castle of aristocrats, whilst the madhouse is simply home to folly. I consider this one of the covert allusions to the English court because Thomas Campion's The Lords' Masque, the very masque James himself commissioned for the marriage of his daughter Elisabeth to Frederick of Bohemia, included an antimasque of 'frantics' or 'lunatics. ${ }^{78}$ In a further intriguing parallel to the Palatine wedding, for which three consecutive nights of masques were planned, Vermandero plans three nights of revels for the marriage of Beatrice-Joanna and de Piracquo and commissions Alibius to provide:

A mixture of our madmen and our fools,

To finish, as it were, and make the fag

Of all the revels, the third night from the first.

Only an unexpected passage over,

To make a frightful pleasure, that is all. (3.3.277-81, emphasis mine)

References to the wedding masque (or masques) in The Changeling are slight and subtle, but occur at key points. This first, above, is just after the audience has witnessed the murder of the groom by Vermandero's servant, De Flores, at the instigation of the bride-to-be. The discordance of such an act is far from the concord symbolized by a wedding masque, meant to represent hopes for a harmonious relationship. The misrule at the castle is further highlighted 
by the principle of contrariety of the antimasque. As with Beaumont and Fletcher's The Maid's Tragedy and Women Beware Women, the mere inclusion of a wedding masque signals that the marriage is doomed before it begins. The following scene witnesses Vermandero, unaware of Piracquo's dispatch, welcoming Alsemero, Beatrice's own choice of husband.

The next mention of the commissioned antimasque of fools is Alibius's request to 'see them once more rehearse before they go', wishing to ensure his new source of revenue will be 'perfect' the following night 'to close up the solemnity' $(4.3 .67,56,57)$, the masques having been reassigned to Beatrice's marriage to Alsemero. In court, antimasque dances were performed by actors (men and boys) and dancing masters. Sabol's study of surviving scores indicates clearly that antimasque dance music has 'rapid scale passages, notes reiterated in rapid succession, abrupt shifts from major to minor and back again, wide skips in melodic lines, cadential formulas calling for trills or vibrato, and impressive rhythmic contrasts', and thus required extensive rehearsal. ${ }^{79}$ Alibius's madmen are to perform a morris, the fools a measure; Lollio's comment, 'I mistrust the madmen most. The fools will do well enough' (59), is heavy with irony: one has to wonder who the real madmen are, having just witnessed Beatrice, her virginity taken by De Flores, bribe her maid Diaphanta to take her place in Alsemero's bed and fake her own virginity test. Beatrice's counterpart, Isabella, is tempted by adultery and the scene in which she disguises herself as a madwoman and dallies with Antonio (who has earlier dropped his disguise and whom she knows to be a gentleman [3.3.130-56]) makes clear the difference between madness and mere foolishness. The use of two plots allows one to be measured against the other: madness is a hidden mental state, foolishness more readily apparent.

The rehearsal Alibius oversees is clearly in costume, for Lollio offers to point out Antonio to Franciscus, saying, 'if you find him not now in the dance yourself I'll show you' (4.1.214-15). Masquers were not officially identified until the moment of unmasking, although in practice there might be clues. What costumes were used is conjecture but, since a stage direction states 'Madmen above, some as birds, others as beasts' (3.3.208 sd), it seems reasonable to imagine them as such, quite fitting for an antimasque of grotesques and the 'frightful pleasure' that Vermandero requested. Lollio is eager to enjoy Isabella himself; he sets up the expectation of a bloody end for Antonio and Franciscus as he goads each to vengeful action to rid themselves of their rival for Isabella. As dancing master and choreographer Lollio is, however, as keen as Alibius for his fee, so he counsels: 'Only reserve him till 
the masque be past' (4.3.213). The rehearsal takes place and Alibius declares it perfect for the masque the following day and looks forward to 'coin and credit' (226) for it.

There is to be no bloody end for Antonio and Franciscus, the disguised antimasquers who have rehearsed madness in the asylum. That fate is reserved for Beatrice-Joanna and De Flores who have been 'more close disguised' (5.3.128) in the castle and practised actual madness. Endeavouring to extend the 'pleasure and continuance' of their affair (5.1.49), they have now also killed Diaphanta. But they have been watched; when Alsemero learns of their liaison, he confines the pair to his closet, commanding: 'rehearse again / Your scene of lust, that you may be perfect / When you shall come to act it to the black audience' (5.3.114-16). The metatheatrical jolt reminds us that they are, of course, actors. It should also remind us that the nobles in the castle are masquers too. There is no direct reference to the other masques nor was there any for the wedding, a dumb show merely shows Beatrice as 'the bride following in great state' ( $4.1 \mathrm{sd}$ ) - but it is clear from Vermandero's earlier request to Alibius that 'the unexpected passage' of fools and madmen is to be a sudden entrance of antimasquers 'the third night from the first' $(3.3 .280,279)$. Taylor and Sabol consider that Middleton revived the choreographed dumb show to create a masque dance effect. ${ }^{80} \mathrm{I}$ believe we are to imagine the earlier nights of offstage masquing and revels; the text offers two suggestive references to Beatrice wearing a mask. Although women commonly wore a mask out of doors, I read these references as part of her masquing costume. Alsemero remarks bitterly to Jasperino that 'The black mask / That so continually was worn upon't / Condemns the face for ugly ere't be seen' (5.3.3-5), and when he confronts Beatrice directly with her whoredom he states: 'There was a visor / O'er that cunning face, and that became you; / Now impudence in triumph rides upon't' (46-8). Even if the mask is metaphorical, like a masquer she has put on the costume of a 'fair faced saint' so that he is left feeling like a 'blind m[an]' (109), recalling Beatrice's prescient warning at their first meeting that eyes should be 'sentinels' to judgement. ${ }^{81}$ This, then, in my reading, is the third masque day and the nobles too will have had to rehearse their dances. In masques the dances were themselves representations of the masque's meaning: 'Our motions, sounds, and words, / Tuned to accords, / Must show the well-set parts / Of our affections and our hearts. ${ }^{82}$ Instead of the graceful foot-work expected of noble masquers, however, Beatrice and De Flores have been metaphorically playing the common country game of chasing couples, 'Barley-break', as De Flores proudly 
declares (163), a dance more like the 'wild distracted measure' (3.3.283) of an antimasque.

Barley-break, or 'Last Couple in Hell', was a country game of capture played by three couples. The couple in the middle, termed Hell, had to catch two of the others who then took their place as catchers. ${ }^{83}$ This game of chasing couples, its rules and its 'hell', provide a useful symbolic image for the amorous chase and for maids trapped into disgrace. As Ann Pasternak Slater, who feels that it can be read as a 'potent symbol for the entire play', states, Sidney's poem Lamon's Tale (unfinished) poetically describes the game through the story of a shepherdess, Urania, who plays at Barleybreak. ${ }^{84}$ Closer yet to the tragic tone of The Changeling is another poem that strikes a didactic note with its telling title, Barley-Breake, OR a Warning to Wantons (1607). ${ }^{85}$ Another shepherdess, Euphema, is pursued by Streton at Barley-break. Her father tries to warn her of the dangers by relating the story of the nymph Calisto who is tricked and 'deflowrd by Iove' (stanza 89). Heedless, Euphema runs off with Streton and allows him to 'doe what he would' (stanza 131). Significantly, in both these poems the men, like De Flores, enjoy being in 'hell'. ${ }^{86}$ Strephon in Lamon's Tale 'thought it heaven so to be drawn to hell' (1 312) and Streton in Barley-Breake 'would for ever, if he might, there dwell' (stanza 17). The symbolic relevance of Barley-break appears to have been well known.

Locked together 'in hell' (5.3.163), De Flores and Beatrice-Joanna are effectively commanded to 'rehearse again' (114) their 'part', their antimasque, 'where howls and gnashings shall be music to you' (117) - music as appropriate to their hell as the 'hollow and infernal music' of the witches' hell in Queens (25). It is to be a danse macabre, as Beatrice and the lord of misrule, De Flores, dance to their deaths. The next moments mimic what was called the 'transformation scene' of a court masque, always at a visually spectacular moment and accompanied by 'loud music'. Transformation or metamorphosis was the theme of all masques (trees are turned into knights, statues come to life, men transformed into flowers are returned to men, blackamoors become white-skinned, gypsies are metamorphosed into courtiers, and so on). It is the moment when antimasquers and masquers are briefly on stage at the same time. Likewise, in The Changeling the two plots here converge: Vermandero enters suddenly with five members of the asylum 'anti-plot' and announces: 'I have a wonder for you' (5.3.121). Alsemero counters: 'No, sir. 'Tis I, I have a wonder for you' (122). Wonder was an effect of tragedy in the period and the motive for learning, a philosophy espoused by Aristotle. ${ }^{87} \mathrm{It}$ 
was also crucial to the masque with its myths and miracles. The word 'wonder' occurs frequently at the moment of transformation. ${ }^{88}$ This exchange between Vermandero and Alsemero arguably resembles a declamatory ayre — not quite a song, yet more than ordinary speech ${ }^{89}$ — inasmuch as Alsemero's lines are a near refrain of the former's (note the repetition not only of 'wonder' but of 'suspicion', 'proof', 'disguised', 'deed', 'hear me', and 'servants', 123-131). The cries of the fatally wounded Beatrice-Joanna startle the stage audience, and Alsemero unlocks the closet. The revelation that follows is indeed one of wonder for Vermandero, who states, 'An host of enemies entered my citadel / Could not amaze like this' (5.3.147-8). His bewilderment measures his lack of earlier understanding, another theory found in Aristotelian texts; he suddenly realizes his patriarchal failure. Before she dies Beatrice confesses to her father and asks Alsemero's forgiveness, her words 'Tis time to die when 'tis a shame to live' (179) echoing Vindice's acceptance of fate after the apocalyptic masque. ${ }^{90}$ As Gail Kern Paster suggests, Beatrice-Joanna's bloodletting image is purgative. ${ }^{91}$ This imagery is also found in Barley-Breake: when Euphema's father dies of shock after learning of her pregnancy, she kills herself, opening her 'veines to let out wanton streames' (stanza 177). Thus in The Changeling, following the tradition of the court masque, the forces of disorder are dispelled.

In what I term The Changeling's transformation scene, as in the court masque all undergo change, 'for it is the transformation of both masquer and spectator, of the whole court, that the masque as form undertakes. ${ }^{92}$ We have seen this in Revenger's Tragedy, Five Gallants, and Women Beware Women where the masques involved all the characters. De Flores and Beatrice-Joanna are transformed: 'Here's beauty changed / To ugly whoredom, here, servant obedience / To a master sin, imperious murder' (5.3.197-9); all the others are changelings too and admit their transformations, including Antonio, who is changed by Isabella's 'powerful beauties, / Whose magic had this force thus to transform me' (3.3.134-5) 'from a little ass as I was to a great fool as I am' (5.3.204-5). All these transformations are contrary, from good to bad; masque transformation was meant to be to 'an ideal, perfected state. ${ }^{93}$ The Changeling inverts the transformation scene of a court masque. Given the debates on the meaning of and precise identification of the 'changeling' and the number of claimants to change in this particular passage, it is surprising that the analogy to the metamorphosis that occurs in masques has not previously been considered, change and transformation being synonymous. ${ }^{94}$ 
Yet, if we see Beatrice's death as the transformation scene of a masque we can see again that the masque ultimately fulfils its aim, the restoration of order. It purges the scene of its sinners and ensures that 'Justice hath so right / The guilty hit, that innocence is quit / By proclamation' (5.3.185-7), gesturing to the Calvinist principles of filial obedience and patriarchal authority. ${ }^{95}$ Richard Hornby suggests that plays within the play and role-playing within a role are devices to explore social or individual concerns in relation to society. By the same argument then, the masque within the play is a device for exploring its fount, the court, in relation to its subjects. Moreover, just as Jonson designed his masques to 'carry a mixture of profit with them no less than delight', 96 The Changeling offers a critique of the English court where a real murder and linked virginity test had taken place. Details of Howard and the Overbury scandal do not need to be retraced here. ${ }^{97}$ My interest lies in how the king and courtiers enjoyed the subversive delight of antimasquing, some even impersonating antimasquers. As Martin Butler reveals, courtiers gradually invaded the antimasque and 'in the late 1610s a series of masques put aristocratic performers in grotesque roles and ... speaking parts. ${ }^{98}$ Particularly significantly, the marquis of Buckingham, the dedicatee of the volume in which the original story of Beatrice-Ioana is found, was an antimasquer, just months before The Changeling, in a masque he sponsored to celebrate his marriage. In The Gypsies Metamorphosed (August 1621) ${ }^{99}$ his family and close circle played speaking roles as charismatic gypsies who picked pockets and told fortunes, Buckingham acting as the gypsy captain. This is essentially what Antonio and Franciscus, 'two of [Vermandero's] chiefest men' (5.2.59), do when they inveigle their way into the asylum and rehearse a mad measure. Indeed Dale Randall states that 'Jonson could scarcely make clearer the overlapping identities of the captain and Buckingham', arguing that the lack of differentiation between masque and antimasque enables him to make the potentially subversive comparison of the king's favourite to a gypsy. ${ }^{100}$ The gypsies are transformed into courtiers but in the epilogue, post-transformation, the gypsy captain (Buckingham) ambiguously states: 'We are gypsies of no common kind, sir'. The Changeling engages with this erosion of the conventional differentiation between masquers and antimasquers and lack of distinction between madmen, fools, and courtiers. They, like Antonio, the dramatists perhaps suggest, may 'Keep [their] caparisons, [they're] aptly clad' (4.3.140).

The court masque was a façade, the court's attempt to mirror itself; it was based on a fable, sometimes with the king portrayed as a god. A mirror, 
however, shows what we look like, not what we are. The masque was court life theatricalized, designed to 'deceive a mighty auditory'.101 Middleton demonstrates his thorough understanding of masquing; he is able to weave individual components of masque dramaturgy into his plays and use the masque episode as a play-with-the-play which encapsulates the over-arching theme. He bends and toys with the formulae, but the outlines of a masque still remain. Identical masquing suits are a means to commit murder rather than to show unity, emblems and torch-bearers expose the vices of the masquers rather than set off their glory; he makes ironic use of masque music, song, and dancing; gods murder; and transformations are from good to bad, as we have seen in The Changeling, with 'beauty changed / To ugly whoredom' and 'servant obedience / To a master sin', rather than the reverse. He challenges the masque as a symbol of magnificence and praise but upholds its ultimate goal, the restoration of order. Just as masques were the perfect vehicles for Jonson's blend of classicism and didacticism, so the masque-within-the-play was the ideal crucible for Middleton's political and social critique.

\section{Notes}

1 Anthony B. Dawson and Paul Yachnin, The Culture of Playgoing in Shakespeare's England (Cambridge, 2001), 42.

2 Sarah Sutherland, Masques in Jacobean Tragedy (New York, 1983), 23-4, 89-90. Sutherland lists Middleton's play-masques as: Your Five Gallants, Michaelmas Term, No Wit, No Help Like a Woman's, More Dissemblers Besides Women, Hengist, King of Kent, The Old Law, Women Beware Women, and The Changeling. Due to misattribution she omits Timon of Athens (it is thought that Middleton wrote scene 2, the banquet and masque of Amazons) and The Revenger's Tragedy (attributed to Tourneur and discussed by Sutherland as such), both played by an adult company, as well as Wit at Several Weapons and The Nice Valour.

3 Thomas Midddleton: The Collected Works, eds. Gary Taylor and John Lavagnino (Oxford, 2007). Througout, all line numbers and quotations from Middleton's plays refer to this edition.

4 There are allusions to and purloins from masques such as Hymenaei, The Lords' Masque, The Gypsies Metamorphosed, and Lovers Made Men.

5 Gary Taylor and Andrew Sabol, 'Middleton, Music and Dance', Gary Taylor and John Lavagnino (eds), Thomas Middleton and Early Modern Textual Culture (Oxford, 2007), 130. 
6 Enid Welsford, The Court Masque: A Study in the Relationship between Poetry and The Revels (Cambridge, 1927), 276-301.

7 Sutherland, Masques; M.R. Golding, 'Variations in the Use of the Masque in English Revenge Tragedy', Yearbook of English Studies 3 (1973), 44-54, doi: http:// dx.doi.org/10.2307/3506855; Inga-Stina Ewbank, 'These Pretty Devices: A Study of Masques in Plays', T.J.B. Spencer and S. Wells (gen. eds), A Book of Masques (Cambridge, 1967), 407-48.

8 See for example Lauren Shohet, Reading Masques (Oxford, 2010), doi: http://dx.doi. org/10.1093/acprof:oso/9780199295890.001.0001, who writes that 'Even in the scripted part of the entertainment, dance surpassed text according to the Neoplatonic philosophical underpinnings of court masques that took well-regulated patterns of intricately moving bodies to mirror the social order, and beyond that the harmonious dance of the cosmos' (30-1).

9 'A man of the time' (1.1.94), 'this our age swims within him'(1.3.23), 'this present minute'(26), 'in these days' (65), 'in this luxurious age wherein we breathe' (112), 'nowadays' (157), 'judgement in this age' (1.4.55).

10 Qtd in Sutherland, Masques, 18.

11 Andrew Sabol (ed.), Four Hundred Songs and Dances from the Stuart Masque (Providence, Rhode Island, 1978), 12.

12 This is a commonplace of cultural materialist work in the 1980s. See also work on anticourt drama such as Albert H. Tricomi, Anticourt Drama in England 16031642 (Charlottesville, 1989).

13 The modesty mask which Piato 'tells' the skull to wear ('Hide thy face now for shame; thou hadst need have a mask now' [3.5.114]) in this case serves well as a disguise, just as a masque vizard does.

14 Stow reports the destruction of the mural that the monk John Lydgate had translated from the French mural he had seen in the Cimitière des Innocents in Paris in 1426; John Stow, A Suruay of London (1598), 264-5. The Middle English text still survives in twelve manuscripts. For this information, the Paris woodcuts, and the English text, see Martin Hagstrøm's website, http://www.dodedans.com. His source is The Dance of Death from Mss Ellesmere 26/A.13 and вM Lansdowne 699, edited with introduction and notes by Beatrice White.

15 See David Lindley (ed.), Court Masques (Oxford, 1995), x. Lindley suggests that Francis Bacon paid over $£ 2000$ for the Masque of Flowers offered at the marriage of the Earl of Somerset to Frances Howard 'entirely ... to earn favour with the King and cement his connection with his favourite'.

16 See Allardyce Nicoll, Stuart Masques and the Renaissance Stage (London, 1937), 38 , on the discretion required in seating arrangements and the careful grading of 
spectators. See also Martin Butler, The Stuart Court Masque and Political Culture (Cambridge, 2008), 50-1. In Beaumont and Fletcher's The Maid's Tragedy, the argument between Calianax and Melantius dramatizes the use of spectator placement as a gauge of status (1.2.64-8).

17 Texts confirm this: 'Then rode the chief masquers in Indian habits, all of a resemblance' (The Memorable Masque, 47) and 'The attire of the masquers was alike in all, without difference' (Masque of Blackness, 57), both in Lindley, Court Masques. See also Barbara Ravelhofer, The Early Stuart Masque: Dance, Costume and Music (Oxford, 2006), who devotes a chapter to costumes and states that 'the theme of concord became one of the underlying principles of Stuart masques'; uniformity and an orderly stage was a 'wishful representation of the wider kingdom' (168).

18 Shohet, Reading Masques, 24.

19 Butler, The Stuart Court Masque, 86-7.

20 Ben Jonson, Barriers at a Marriage, in Lindley, Court Masques, 15.

21 Ewbank has traced an early use of a masque to commit murder in Woodstock (15914) and historical evidence linking masquing and murder in Holinshed ('These Pretty Devices', 438).

22 Golding, 'Variations in the Use of the Masque', 45.

23 Women Beware Women, 2.2.430.

24 Stephen Orgel, The Illusion of Power (Cambridge, 1975), 40.

25 An impresa is a motto, traditionally no longer than three words; an emblem could be a lengthy poem. See Nicoll, Stuart Masques, 154.

26 Rosemary Freeman, English Emblem Books (London, 1948), 99.

27 Ibid, 90-4.

28 Nicoll, Stuart Masques, 154.

29 Ibid, 155.

30 Samuel Daniel, The Vision of The Twelve Goddesses, 149 in Spencer and Wells, Book of Masques, 26.

31 Middleton was not alone in using a procession of emblematised suitors as a wooing device. Jonson uses it similarly ironically in his anti-court satire of 1600, Cynthia's Revels, before he wrote any court masques. In Marston's Antonio and Mellida (5.1), Galeatzo, Matzagente, and Ballurdo, each carrying a device with a word, court Mellida, Rossaline, and Flavia during a masque.

32 Ralph Alan Cohen, 'Introduction to Your Five Gallants', Collected Works, 596.

33 Nicoll, Stuart Masques, 156.

34 Peter Walls, Music in The English Courtly Masque, 1604-1640 (Oxford, 1996), 46.

35 Anne Daye, 'Torchbearers in the English Masque', Early Music 26 (1998), 247, doi: http://dx.doi.org/10.1093/em/26.2.246. 
36 See Ben Jonson, Christmas His Masque (1l 83-4), in Lindley, Court Masques, 111: 'to bring them here, and to lead them there / And home again to their own porches'.

37 See Nicoll, Stuart Masques, 213. In Chapman's Memorable Masque the chief masquers were 'in Indian habits, all of a resemblance ... the torch-bearers habits were likewise of the Indian garb ... the humble variety whereof struck off the more amply the masquers' high beauties, shining in the habits of themselves' $(47,75-8)$.

38 Daye, 'Torchbearers', 249.

39 A term used in both Revenger's Tragedy (5.2.6) and Your Five Gallants (5.1.239).

40 'Shield-bearer', 2.n, Oxford English Dictionary Online.

41 Beaumont and Fletcher, The Maid's Tragedy, ed. T.W. Craik (Manchester, 1988), 1.1.8-10,

42 Cohen, 'Introduction to Your Five Gallants', Collected Works, 596.

43 Jonson, Queens, 10-12 in Lindley, Court Masques, 35.

44 Jonson, Haddington Masque, 100-1, http://www.one.act-plays.com/hue_and_cry_ after_cupid.html.

45 Sabol, Four Hundred Songs and Dances, 3, n. 1.

46 Francis Beaumont, Masque of the Inner Temple (246-8), Spencer and Wells, Book of Masques, 139.

47 Shakespeare's The Winter's Tale adopts an antimasque of satyrs from Oberon (1 January 1611) with the borrowing made clear by the shepherd's servant telling Polixenes: 'One three of them, by their own report, sir, hath danced before the king' (WT 4.4.337-8) and The Two Noble Kinsmen (3.5.137-48), appropriates the second antimasque, Iris's parody of May games, of Beaumont's Masque of the Inner Temple and Gray's Inn (20 Feb 1613). See Ashley Thorndike, 'Influence of the Court-Masques on the Drama, 1608-15', PMLA 15 (1990), 114-20. Taylor and Sabol, 'Middleton, Music and Dance', 130, suggest that 'one of more of the witches' dances in Middleton's adaptation of Macbeth (1616) may have been recycled from Jonson's Masque of Queens'.

48 According to Sabol, Four Hundred Songs and Dances, the word antimasque usually suggested the several and various meanings: it was 'dance music used before the main masque (ante-masque), its action contrasted with that of the masque proper (anti-masque), it often involved comic action (antic-masque), and some of its dances were ancient (antique-masque)' (12).

49 Taylor, Collected Works, 1323.

50 Masque dancing consisted of two parts: the formal measures and the lighter revels. This time of mingling is exploited by the dramatists to arrange a hasty marriage. As Sabol explains, sometimes the word 'revels' is loosely applied to both parts of the dancing (Four Hundred Songs and Dances, 15). 
51 Dale B.J. Randall, Jonson's Gypsies Unmasked (Durham, NC, 1975$), 157$.

52 John Potter, 'In Time of Sports': Masques and Masking in Middleton's Women Beware Women', Papers on Language and Literature 18.4 (1982), 383; see also Ewbank, 'These Pretty Devices', 446.

53 Margaret Shewring and J.R. Mulryne, 'Dancing Towards Death: Masques and Entertainments in London and Florence as precedents for Thomas Middleton's Women Beware Women', Dance Research: The Journal of the Society for Dance Research 25.2 (2007), 136, doi: http://dx.doi.org/10.3366/drs.2007.25.2.134.

54 Ibid, 135.

55 Women, Beware Women: A Tragedy, John Jowett (ed.), Collected Works, 1489.

56 Francesco was only twenty-three at his marriage to Bianca Capello.

57 Another, even more complete, is in Beaumont and Fletcher's The Maid's Tragedy, 1.2 .

58 Walls, Music in The English Courtly Masque, 46.

59 It is not clear whether this is a second raised stage, since Bianca, Duke, and guests 'Enter, above' ( $5.1 .38 \mathrm{sd}$ ). Nor is it clear how the quick descent was managed in production. Leslie Thomson discusses the problem of this stage direction as well as Middleton's general emblematizing of the upper stage but does not refer to this masquing convention. See Thomson, "Enter Above”: The Staging of Women Beware Women', Studies in English Literature, 1500-1900 26 (1986), 331-43, doi: http:// dx.doi.org/10.2307/450511.

60 Ravelhofer, Early Stuart Masque, 87.

61 Ibid.

62 Elizabeth Zeman Kolkovich, "Drabs of State Vext”: Violent Female Masquers in Thomas Middleton's Women Beware Women', Mara R. Wade (ed.), Gender Matters: Discourses of Violence in Early Modern Literature and the Arts (Amsterdam, 2014), 295-306, 298.

63 Laura Severt King, 'Violence and the Masque: A Ritual Sabotaged in Middleton's Women Beware Women' Pacific Coast Philology 21.1-2 (1986), 46, doi: http://dx.doi. org/10.2307/1316409.

64 See Potter, 'In Time of Sports', 380, and Albert H. Tricomi, 'Middleton's Women Beware Women as Anticourt Drama', Modern Language Studies 19.2 (1989), 73, doi: http://dx.doi.org/10.2307/3195193.

65 Orgel, Illusion of Power, 49.

66 Ibid.

67 Ibid, 50. 
68 David Nicol, Middleton \& Rowley: Forms of Collaboration in the Jacobean Playhouse (Toronto, 2012), 4, describes the Middleton/Rowley team as 'the greatest collaborators of their age'.

69 The full title of Reynolds's work is The Triumphs of God's Revenge against the Crying and Execrable Sin of Murder. The story adapted by the dramatists is Book 1 (1621), 'Historie IV'.

70 Joan M. Walmsley, John Reynolds, Merchant of Exeter, and his Contribution to the Literary Scene 1620-1660 (Cambridge, 1991), 15, 32, 173. In his 'Epistle Dedicatorie', which dedicates the whole work (six books) to Charles I. Reynolds writes, 'The former three Bookes had the Honour and Happinesse to bee perused by the Judicious Eye of King JAMES, your Renowned Father, (of happy Memory) In whose incomparable Judgement they failed not of Approbation' (London, 1635), A1v. Walmsley considers that James's approval would have contributed to the publication of a folio edition.

71 Scholars credit Rowley with writing the subplot but clearly the two were exceptionally close collaborators, since a calculated system of contrariety operates across both plots, with matching vocabulary and imagery.

72 Sabol, Four Hundred Songs and Dances, 7, 12.

73 Hugh Craig, 'Jonson, the antimasque and the "rules of flattery", David Bevington and Peter Holbrook (eds), The Politics of the Stuart Court Masque (Cambridge, 1999), 188.

74 Muriel Bradbrook observed, without elaborating on this point, that the relationship of plot to subplot 'is precisely that of masque and antimasque, say the two halves of Jonson's Masque of Queens'; see her Themes and Conventions of Elizabethan Tragedy (Cambridge, 1935), 221.

75 This parallelism has been well documented by, for example, William Empson, Some Versions of Pastoral (London, 1935), 27-86 and A.L. Kistner and M.K. Kistner, 'The Five Structures of The Changeling', Modern Language Studies 11.2 (1981), 4-53, doi: http://dx.doi.org/10.2307/3194565.

76 Reynolds, The Triumphs of God's Revenge, A4v.

77 Ibid, T2v.

78 'This was the first royal wedding to take place in England since the marriage of Mary Tudor to Philip of Spain in 1554' and 'such magnificence had not been witnessed for a nuptial event since ... 1501. The total cost of the Palatine wedding ceremony and festivities included — came to an astounding £93,293’. Kevin Curran, Marriage, Performance and Politics at the Jacobean Court (Aldershot, 2009), 89. The wedding would assuredly remain in cultural memory just nine years later. 
Sutherland also remarks that the lunatics dance might resemble the 'mad measure' from The Lords' Masque (Masques, 108).

79 Sabol, Four Hundred Songs and Dances, 13.

80 Taylor and Sabol, 'Middleton, Music and Dance', 130.

81 'Be better advised, sir / Our eyes are sentinels unto our judgements, / And should give certain judgement what they see; / But they are rash sometimes, and tell us wonders / Of common things, which when our judgements find, / They can then check the eyes, and call them blind' (1.1.71-6).

82 Daniel, Tethys' Festival, 336-9, in Lindley, Court Masques, 62.

83 Descriptions of 'Barley-break' are widely available. See, for example the $O E D$. 'Barley-break' appears in the work of other poets and playwrights, such as Dekker and Massinger.

84 Ann Pasternak-Slater, 'Hypallage, Barley-Break, and The Changeling', The Review of English Studies 34 (1983), 429-40, doi: http://dx.doi.org/10.1093/res/xxxiv.136.429.

85 The text of Barley-Breake by W.N. Gentleman (Anon.), based on the edition by Alexander B. Grosart (1877), can be found on the Renascence Editions site http:// www.luminarium.org>.

86 'Hell' was slang for 'vagina' in the period.

87 J.V. Cunningham, Woe or Wonder: The Emotional Effect of Shakespearean Tragedy (Chicago, 1951), 65.

88 'Help, help all tongues to celebrate this wonder / The voice of Fame should be as loud as thunder' (Jonson, Masque of Queens, 654-5, in Lindley, Court Masques); 'Feed apace then, greedy eyes, / On the wonder you behold' (Daniel, Tethys' Festival, 355-60, in Lindley, Court Masques); 'he the wonder is of tongues, of ears, of eyes' (Jonson, Oberon 239, 246, in Spencer and Wells, Book of Masques); 'Who can more affright / The eye with magic wonders?' (Campion, Lord Hay's Masque, 365-6, in Lindley, Court Masques); 'And from thy hand let wonders flow tonight' (Campion, The Lords' Masque, 135, in Spencer and Wells, Book of Masques). In Jonson's Vision of Delight Wonder appears in person: 'How better than they are all things made / By Wonder!, (157-8, in Ben Jonson: Selected Masques, ed. Stephen Orgel (New Haven, 1970).

89 A declamatory ayre was a musical representation of actual speech, inherently dramatic. Declamatory elements were especially appropriate in the masque. See Walls, Music in The English Courtly Masque, 67. Middleton was heavily influenced by the music of masques. In The Nice Valour (1622) he adopts the dignified form of recitative, which Jonson used to enhance noble masquers, for an exchange of bursts of laughter and bawdy. There is also in Valour a clear purloin of a unique dance 
sequence from the long second antimasque dance The Gypsies Metamophosed, again subverted for satirical purpose.

90 'Tis time to die when we are ourselves our foes' (Revenger's Tragedy 5.3.109).

91 Gail Kern Paster, The Body Embarrassed: Drama and the Disciplines of Shame in Early Modern England (Ithaca, 1993), 89.

92 Stephen Orgel 'The Poetics of Spectacle', New Literary History 2.3, (1971), 384.

93 Sabol, Four Hundred Songs and Dances, 12.

94 In the 1653 quarto Antonio is identified as 'the' changeling in the dramatis personae, but it is thought this may have been a later interpolation. The OED glosses five senses for the noun 'changeling' and a number of commentators speculate on which of the many characters who are subject to change might be the dramatists' intended changeling; see, for instance: Empson, Some Versions of Pastoral, 50-2; Bradbrook, Themes and Conventions, 213-24; Pasternak-Slater, 'Hypallage', 429; and John Stachniewski, 'Calvinist Psychology in Middleton's Tragedies', Three Jacobean Tragedies, ed. R.V. Holdsworth (Basingstoke, 1990), 229.

95 This marries with the Calvinist persuasion of the source text's author, Reynolds, and with Middleton's Calvinist theology. See, for example, Margot Heinemann, Puritanism and Theatre: Thomas Middleton and Opposition Politics under the Early Stuarts (Cambridge, 1980) and Stachniewski, 'Calvinist Psychology'.

96 Jonson, Love's Triumph, 1-3, cited in Orgel, Illusion of Power, 43.

97 See in particular David Lindley, The Trials of Frances Howard (London, 1993).

98 See Butler, The Stuart Court Masque, 32.

99 Performed on three occasions: at Burley-on-the-Hill on 3 August 1621, at Belvoir Castle, the country seat of Buckingham's father-in-law, The Earl of Rutland, on 5 August, and at Windsor Castle in September (date unclear).

100 Randall, Jonson's Gypsies Unmasked, 156.

101 Middleton, $A$ Game At Chess (5.2.33). 